\title{
Nutritional and metabolic assessment of critically ill children
}

\author{
Pediatric ICU of the Hospital do Servidor Público Estadual de São Paulo "Francisco Morato de Oliveira" and Hospital \\ São Paulo - Universidade Federal de São Paulo, Escola Paulista de Medicina - São Paulo, Brazil
}

\begin{abstract}
In a prospective study, with the objective of determining the metabolic profile, response to nutrient supply, and role of nutritional and metabolic assessment parameters in children admitted to a pediatric ICU, 11 patients in the age group 2-12 were studied. The assessment was carried out during the first 72 hours of admission, and again seven days later, and included the following parameters: caloric supply; nitrogen supply; prealbumin serum level; urinary urea nitrogen; nitrogen balance and creatinine-height index. The evolution of the parameters in the two stages of the study showed the following results: The urinary urea nitrogen median value at admission was $7.5 \mathrm{~g} / \mathrm{m}^{2}$ of corporeal surface, and did not present significant changes seven days later. There was a significant increase in caloric supply from 42.9 to $70,3 \mathrm{kcal} / \mathrm{kg}$, and in nitrogen supply, from 4.7 to $10.2 \mathrm{~g} / \mathrm{m}^{2}$ of corporeal surface $p 0.01$. The level of nitrogen balance rose from -5.6 to $2.5 \mathrm{~g} / 24 \mathrm{~h}(\mathrm{p}<0.03)$, and that of prealbumin, from 16.7 to $26.3 \mathrm{mg} / \mathrm{dl}(\mathrm{p}<0.03)$. There was a significant reduction in the creatinine-height index, from 86.2 percent to 55.0 percent $p 0.01$. The magnitude of urinary urea nitrogen excretion at admission varied $2.5-13.8 \mathrm{~g} / \mathrm{m}^{2}$ of corporeal surface. Based on this parameter, it was not possible to establish a characteristic metabolic profile for the conditions studied. Notwithstanding an increase in the protein and caloric supply, prealbumin level and nitrogen balance observed in the second stage of the study, the patients lost muscle mass and entered into a malnutrition process, probably due to intense protein catabolism and the poor response to nutrition supply that occurs in metabolic stress.
\end{abstract}

UNITERMS: Nutritional assessment. Nutritional support. Nitrogen balance. Prealbumin.

\section{INTRODUCTION}

$\mathrm{T}$ The development of new techniques in enteral and parenteral nutrition has led to an improvement in the therapeutic support for children with acute conditions, allowing the benefits of nutritional support to be favorably reflected in the parameters of hospital evolution. This has raised interest in an objective

\author{
Address for correspondence: \\ Heitor Pons Leite \\ Disciplina de Nutrição e Metabolismo \\ Depto de Pediatria - Escola Paulista de Medicina \\ Universidade Federal de São Paulo \\ Rua Loefgreen, 1647 - Vila Clementino \\ São Paulo/SP - Brasil - CEP 04040-032
}

metabolic and nutritional assessment, with the purpose of optimizing the supply of nutritional support to these patients.

The metabolic changes resulting from infectious processes or acute injuries lead to a metabolic response that deeply affects the production, use and demand for nutrients at the cellular level. This results in a rapid process of malnutrition, with severe consequences for the patient.' In this situation, a nutritional assessment does not only detect the changes in corporeal composition and organic function, consequent to a poor food intake, but also identifies the changes caused by an increase in the consumption, degradation and loss of nutrients, and thus can be considered a nutritional and metabolic assessment.

In clinical practice, the resources used to assess the adequacy of nutritional support in adult patients with metabolic stress are based on an anthropometric 
assessment, plasmatic protein dosage, nitrogen balance and immunological function tests. ${ }^{2}$ This study aims to evaluate the nutritional and metabolic profile in response to a supply of nutrients and the role of metabolic and nutritional assessment parameters in children admitted to an intensive care unit.

\section{PATIENTS AND METHODS}

Children admitted to the pediatric intensive care units of the Hospital do Servidor Público Estadual de São Paulo and the Hospital São Paulo - Escola Paulista de Medicina were assessed as to their metabolic and nutritional status, and supply of nutrients. The study was approved by the ethics committees of these hospitals and was conducted between September 1991 and January 1993. The assessment was carried out during the first 72 hours of admission to the ICU and again seven days later. It included the following parameters:

- anthropometric assessment: weight and height at admission.

- laboratorial assessment: prealbumin, urinary urea nitrogen, nitrogen balance, and creatinine-height index (at admission and again seven days later).

Children who had the prospect of undergoing parenteral and/or enteral nutrition for a period of seven or more days were initially included in the study. The criteria for exclusion were: age under 3 months; patients with renal insufficiency; hepatic insufficiency or diarrhea; and those who, in the second stage of assessment, had had their protein and caloric supply interrupted or reduced in the previous 48 hours. Of the 15 patients initially included, four did not complete the second stage of assessment, and 11 patients effectively participated. The age group ranged from 4 to 12 years, with a median of 9 years. Eight were male and three were female.

The Holliday \& Segar ${ }^{3}$ method was used to estimate caloric needs. The protein and caloric supply administrated parenterally and/or enterally was recorded daily during the commitment period in the ICU. Weight and height and respective ratios were compared to World Health Organization standards. ${ }^{4}$ A modified Waterlow criteria was adopted to classify nutritional status. ${ }^{5.6}$

Urinary urea nitrogen and creatinine were measured in 24-hour urine (the former by automated urease method). Nitrogen balance, obtained by the difference between the nitrogen supply and the measured urinary excretion plus estimated fecal excretion, was calculated according to WILMORE ${ }^{7}$. The creatinine height index was expressed by the formula: ( $\mathrm{mg}$ of creatinine excreted in 24-hour urine by the patient divided by $\mathrm{mg}$ of creatinine in 24-hour urine of a normal child of the same height) $x 100$. For interpreting values of creatinine height index, the standard of normality described by MERRIT \& BLACKBURN $^{8}$ was adopted. Urinary creatinine was measured by the automated alkaline picrate method. Serum prealbumin was measured by the simple radial immunodifusion method, using M-Partigen plaques (Boehring®).

\section{STATISTICAL ANALYSIS}

The Wilcoxon ${ }^{9}$ test was used in order to analyze the variation of values of biochemical parameters, and the caloric and nitrogen supply obtained in both phases of the study. Values are expressed in median. The level set for rejecting the hypothesis of equality was 0.05 ( 5 percent).

Table 1

Patients according to diagnosis, urinary urea nitrogen values ( $\mathrm{g} / \mathrm{m} 2$ of corporeal surface) and nutritional status at admission.

\begin{tabular}{lcc}
\hline Diagnosis & U.U.N. & Nutritional status \\
\hline Guillain Barré Syndrome & 3.9 & Wasted \\
Cerebelar astrocytoma postop. & 7.2 & Eutrophy \\
Bone marrow aplasia/sepsis & 12.5 & Eutrophy \\
Cerebral abscess & 6.8 & Eutrophy \\
Head trauma & 9.7 & Eutrophy \\
Polytrauma/head trauma & 10.2 & Eutrophy \\
Head trauma & 3.4 & Wasted \\
Meningitis & 7.5 & Wasted \\
Meningitis & 6.9 & Wasted \\
Polytrauma/head trauma & 13.9 & Eutrophy \\
Medulloblastoma/postop. & 10.5 & Eutrophy \\
\hline
\end{tabular}

U.U.N.: Urinary urea nitrogen 
Table 2

Children according to prealbumin $(\mathrm{mg} / \mathrm{dl})$, nitrogen balance $(\mathrm{g} / 24 \mathrm{~h})$ and creatinin-height index in both phases of the study.

\begin{tabular}{cccccc}
\hline \multicolumn{2}{c}{ Prealbumin } & \multicolumn{2}{c}{ Nitrogen balance } & \multicolumn{2}{c}{ Creatinin-height index } \\
\hline Admission & $7^{\text {th }}$ day & Admission & $7^{\text {th }}$ day & Admission & $7^{\text {th }}$ day \\
\hline 11.4 & 10.0 & -1.12 & -2.5 & 68.9 & 55.0 \\
41.0 & 43.0 & -1.0 & 2.9 & 68.3 & 51.9 \\
16.0 & 21.0 & -1.5 & -4.0 & 100.0 & 53.0 \\
11.0 & 36.0 & -10.0 & -5.5 & 42.5 & 32.9 \\
24.0 & 39.0 & -2.7 & -3.3 & 59.9 & 44.5 \\
17.5 & 20.8 & -12.4 & 5.7 & 99.3 & 55.9 \\
41.0 & 43.0 & -1.6 & 2.7 & 73.0 & 69.0 \\
20.8 & 26.3 & -8.8 & 0.3 & 100.0 & 74.2 \\
16.7 & 14.3 & -7.0 & -4.1 & 86.2 & 99.6 \\
14.3 & 12.1 & -15.8 & -4.9 & 90.0 & 41.6 \\
11.4 & 31.2 & -5.6 & 1.7 & 100.0 & 100.0 \\
\hline
\end{tabular}

\section{RESULTS}

Table 1 divides patients according to diagnosis at admission, urinary urea nitrogen values, and nutritional status at admission. Patients suffering from astrocytoma, medullar aplasia, and medulloblastoma had been given corticosteroids. Table 2 shows individual values of biochemical parameters obtained in both phases of the study. Table 3 shows the evolution of nutritional parameters and the results of statistical analysis. The median value of urinary urea nitrogen at admission was $7.5 \mathrm{~g} / \mathrm{m} 2$ of corporeal surface, varying from 3.4 to 13.9 $\mathrm{g} / \mathrm{m} 2$. Protein and caloric supply and serum prealbumin levels showed a significant increase in the second phase of the study, as did nitrogen balance, although it continued to be a negative value. There was a significant reduction in the creatinine-height index. The excretion of urea nitrogen in urine did not change significantly in the second stage of assessment; that is, patients remained hypercatabolic.

\section{DISCUSSION}

In either nutritional or metabolic assessments, the ideal parameter should present good sensitivity and specificity both in the assessment prior to treatment and in the monitoring of the response to nutritional intervention. At this time, this parameter has not been developed.

Although anthropometric measurements are useful to evaluate nutritional changes prior to admission and to document long-term therapeutic effects, they do not adequately reflect the acute nutritional changes which occur in metabolic stress situations, such as trauma, sepsis, and immediate postoperative period of major surgeries. Although these situations lead to a reduction in cellular mass, there is an absolute expansion of extracellular fluid which results in an underestimated weight loss. Weight gain may actually occur, caused by fluid accumulation in the third space, due to an increase in the permeability of capillary endothelium which occurs in these situations. This "extra" fluid is eliminated within a few days, unless there is a persistence or exacerbation of the metabolic response to stress.

We know that the urinary excretion of products originating from the degradation of skeletal muscle reflects the intensity of hypercatabolism and the extent of metabolic response to stress. ${ }^{10}$ The use of the formula based on the 24-hour urine urea nitrogen is useful in estimating total losses of nitrogen, " and has been used to assess the magnitude of metabolic response to stress in adult patients. ${ }^{12}$

The magnitude of urinary urea nitrogen excretion observed at admission of the studied patients varied, depending on their pathologies, being greater in 


\section{Table 3}

Evolution of nutritional and metabolic parameters*.

\begin{tabular}{lccc}
\hline Parameter & Admission & $7^{\text {th }}$ day & $\mathrm{p}$ \\
\hline Energy supply $(\mathrm{kcal} / \mathrm{kg})$ & 42.9 & 70.3 & $\mathrm{p}>0.01$ \\
Nitrogen supply $\left(\mathrm{g} / \mathrm{m}^{2}\right)$ & 4.7 & 10.2 & $\mathrm{p}<0.01$ \\
Prealbumin $(\mathrm{mg} / \mathrm{dl})$ & 16.7 & 26.3 & $\mathrm{p}<0.03$ \\
U.U.N. $\left(\mathrm{g} / \mathrm{m}^{2} 24 \mathrm{~h}\right)$ & 7.5 & 6.9 & $\mathrm{NS}$ \\
Nitrogen balance $(\mathrm{g} / 24 \mathrm{~h})$ & -5.6 & -2.5 & $\mathrm{p}<0.03$ \\
Creatinin-height index $(\%)$ & 86.2 & 55.0 & $\mathrm{p}<0.01$ \\
\hline
\end{tabular}

${ }^{\star}$ Median values

NS: no significance

patients with several injuries, and reflected the extent of muscle protein breakdown and hypercatabolism. A study of hypercatabolic children shows comparable values, and a wide variation was also observed, with values ranging from 0.99 to $13.7 \mathrm{~g} / \mathrm{m} 2$ of corporeal surface in 24 hours. ${ }^{13}$ The high values observed in a child with medullar aplasia/sepsis and in another child with postoperative medulloblastoma can be explained by the fact that these children had been given corticosteroids, which must be taken into account when interpreting values of this parameter. Corticotherapy increases the urinary excretion of nitrogen ${ }^{14}$ and, in the patients mentioned above, probably caused an additional effect of the drug on the hypercatabolism caused by the sepsis and craniotomy, respectively. The urinary urea nitrogen value obtained in a child suffering from Guillain-Barré syndrome suggests the existence of a hypercatabolic state, probably triggered by endocrine and inflammatory components of the disease. An increase in urinary urea nitrogen excretion was also observed by ROUBENOFF et al. ${ }^{12}$ in adults with Guillain-Barré syndrome. In that study, the authors draw attention to the false impression of the maintenance of a good nutritional status in patients suffering from this disease; this often delays the onset of an adequate nutritional support.

Nitrogen balance, despite the difficulties in collecting urine for 24 hours and in the presence of diarrhea (factors which limit its use with children), is still the simplest and fastest method to assess shortterm protein metabolism and to evaluate the efficacy of nutritional treatment in hypercatabolic patients.

Transport plasma or visceral proteins are indicative of protein and caloric malnutrition, and can be used (particularly, the prealbumin) to assess surgical risks in children who undergo major surgeries. ${ }^{15}$ This protein, whose 2-day half-life provides a fast response to changes in protein and caloric supply, has been shown to be a good parameter in monitoring the response to nutritional support supply. ${ }^{16,17}$

However, the concentrations of these proteins drop rapidly in response to metabolic stress. ${ }^{18}$ Other factors, apart from the availability of nutrients, may affect serum concentrations of visceral proteins. The most significant factor is the release of mediators of metabolic response to stress, which regulate protein synthesis in hepatocytes. A tissue lesion seems to promote the production of cytokines by macrophages, which in turn induces hepatocytes to increase production of acute phase proteins at the expense of the transport protein synthesis. In this study, the visceral protein synthesis, ${ }^{15}$ is represented by an increase in prealbumin levels and followed the protein caloric supply, but might have also reflected a decrease in the intensity of the acute phase response.

In spite of the increases observed in: the protein caloric supply; prealbumin levels; and nitrogen balance in the second phase of the study, patients lost muscle mass, and entered into a process of malnutrition, which was demonstrated by a decrease in their creatinineheight index. This malnutrition is due mainly to the intense protein catabolism that occurs in metabolic stress, and to the poor response to nutritional treatment. The effects of hypercatabolism may be partially compensated for by an increase in caloric protein supply, ${ }^{1.19 .20}$ which, however, does not generally meet the requirements of an increase in metabolic demands, and in turns leads to loss of muscle mass. The necessity to reduce hydration, frequent in gravely ill patients, may limit the administration of nutrients, and aggravate the imbalance between supply and demand. In this study, as the patients were mainly children suffering from central nervous system conditions presenting cerebral edema, it was necessary to reduce fluid administration. This limited their nutrient supply and demonstrated that it is difficult to provide adequate nutritional support to patients under hydric restraint.

Considering the variability of pathologies and the small number of children studied in this paper, it was not possible to establish a characteristic metabolic profile. Even taking into account the limitations of available methods and the existing difficulties in applying them, an objective nutritional and metabolic assessment is an essential part in nutritional support planning, which, integrated with other therapeutic measures, may contribute to reducing mortality and 
morbidity in children admitted to intensive care units. Further studies using larger and more homogeneous samples are needed to determine the metabolic profile and to identify more sensitive and specific parameters to assess the adequacy of nutritional support in critically ill children.

\section{ACKNOWLEDGMENT}

The authors wish to thank Dr. Sergio Malaman, of the Department of Clinical Pathology at the Hospital do Servidor Público Estadual de São Paulo, for his support.

\section{Resumo}

Em estudo prospectivo, objetivando determinar o perfil metabólico, a resposta à oferta de nutrientes e o papel dos parâmetros de avaliaçăo nutricional e metabólica em crianças admitidas em UTI Pediátrica, foram estudados 11 pacientes na faixa etária entre 2 e 12 anos. A avaliação foi realizada nas primeiras $72 \mathrm{~h}$ de admissão e após 7 dias de internação e compreendeu os parâmetros: oferta calórica, oferta de nitrogênio, nível sérico de pré-albumina, nitrogênio ureico urinário, balanço nitrogenado e índice creatinina-altura. A evolução dos parâmetros nas duas etapas do estudo mostrou os seguintes resultados: $O$ valor mediano do nitrogênio ureico na entrada foi de $7,5 \mathrm{~g} / \mathrm{m}^{2}$ de superfície corpórea, não sofrendo alteração significante após 7 dias. Houve um aumento significante na oferta calórica de 42,9 para $70,3 \mathrm{kcal} / \mathrm{kg}$ de peso e na oferta de nitrogênio de 4,7 para $10,2 \mathrm{~g} / \mathrm{m}^{2}$ de superfície corpórea $(\mathrm{p}<0,01)$. O nível do balanço nitrogenado subiu de $-5,6$ para $-2,5 \mathrm{~g} / 24 \mathrm{~h}(\mathrm{p}<0,03)$ e o de préalbumina de $16,7 \mathrm{para} 26,3 \mathrm{mg} / \mathrm{dl}(\mathrm{p}<0,03)$. Houve uma redução significante no índice creatinina-altura, que passou de $86,2 \%$ para $55,0 \%(p<0,01)$. A magnitude da excreção do nitrogênio ureico urinário na admissão foi variável $\left(2,5\right.$ a $13,8 \mathrm{~g} / \mathrm{m}^{2}$ de superfície corpórea), não sendo possivel, com base neste parâmetro, traçar um perfil metabólico característico para as patologias estudadas. Apesar dos aumentos da oferta protéico-calórica, do nivel de pré-albumina e do balanço nitrogenado observados na segunda etapa do estudo, os pacientes perderam massa muscular entrando em processo de desnutriçāo, provavelmente devido ao intenso catabolismo protéico e à pobre resposta ao suporte nutricional que ocorrem no estresse metabólico.

\section{REFERENCES}

1. Cerra B. Hypermetabolism, organ failures and metabolic support. Surgery 1987;101(1):1-13.

2. Bole JM, Garre MA, Youinou PY. Simple assessment of the nutritional status in the critically ill patient. Resuscitation 1984;11:233-41.

3. Holliday MA, Segar WE. The maintenance need for water in parenteral fluid therapy, Pediatrics 1957;19:823-32.

4. Organizacion Mundial De La Salud. Medición del Cambio del Estado Nutricional. Geneva: OMS, 1983:105.

5. Batista Filho M, Sigulen DM, Nóbrega FJ. Nomenclatura e

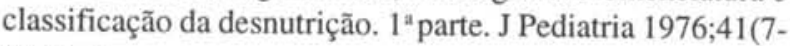
8):45-51.

6. Waterlow JC. Classification and definition of protein-calorie malnutrition. Br J Med 1972;3:566-9.
7. Wilmore DW. The metabolic management of the critically ill. New York: Plenun Publishing Corporation, 1980:262.

8. Merrit RJ, Blackburn GL. Nutritional assesment and metabolic response to illness of the hospitalized child. In: Suskind RM, ed. Textbook of Pediatric Nutrition. New York: Raven Press, 1981.

9. Siegel, S. In: Trilla, ed. Estadistica no parametrica. Mexico, 1975:346.

10. Cuthbertson D, Tilstone WJ. Metabolism during the post injury period. Adv Clin Chem 1969;12:1-55.

11. Velasco N, Long CL, Otto DA, Davis N, Geiger JW, Blakemore, WS. Comparison of three methods for the estimation of total nitrogen losses in hospitalized patients. JPEN 1990;14(5):517-22.

12. Roubenoff RA, Borel CO, Hanley DF. Hypermetabolism and hypercatabolism in Guillain-Barré Syndrome. JPEN 1992;16(5):464-72. 
13. Mickell JJ. Urea nitrogen excretion in critically ill children. Pediatrics 1982;70(6):949-54.

14. Haynes RC, Murad F. Hormona adrenocorticotrofica, esteroides adrenocorticales y sus análogos; sintéticos inibidores de la biosíntesis de esteroides corticosuprarenales. In: Goodman y Gilman, eds. Las bases farmacológicas de la terapéutica. Buenos Aires: Panamericana, 1982:1430-58.

15. Leite HP, Fisberg M, Novo NF, Nogueira EBR, Ueda IK. Nutritional assessment and surgical risk markers in children submitted to cardiac surgery. SPMJ 1995;113(1):706-14.

16. Chwals WJ, Fernandez E, Charles BJ. Serum visceral protein levels reflect protein-calorie repletion in neonates recovering from major surgery. J Ped Surg 1992; 27(3):317-21.
17. Thomas MR, Massoudi M, Byrne J, Mitchel MA, Eggert JD, Chan GM, et al. Evaluation of transthyretin as a monitor of protein-energy intake in preterm and sick neonatal infants. JPEN 1988;12(2):162-6.

18. Leite HP. Avaliação do estado nutricional e indicadores de risco cirúrgico em crianças submetidas a cirurgia cardíaca. São Paulo, 1992. (Master Thesis, Escola Paulista de Medicina).

19. Fürs P, Stehle P. Are Intravenous Amino Acid Solutions Unbalanced? New Horizons 1994;2(2):215-23.

20. Shaw J, Wolfe R. An integrated analysis of glucose, fat, and protein metabolism in severely traumatized patients. Ann Surg 1989;209(1):63-72. 